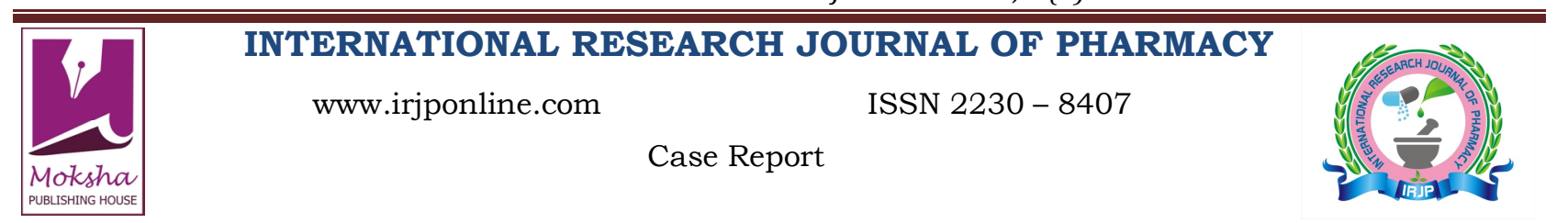

\title{
ROLE OF SAMSHAMAN THERAPY IN THE MANAGEMENT OF EKAKUSHTHA (PSORIASIS): A CASE REPORT
}

Antiwal Meera ${ }^{1}$ and Singh Jai Prakash ${ }^{2}$

${ }^{1}$ Senior Resident, Department of Kayachikitsa, IMS, BHU, Varanasi, India

${ }^{2}$ Lecturer, P.G.Department of Kayachikitsa, National Institute of Ayurveda, Jaipur, Rajasthan, India

Email: drjp98@yahoo.co.in

Article Received on: 18/02/13 Revised on: 21/03/13 Approved for publication: 11/04/13

DOI: 10.7897/2230-8407.04449

IRJP is an official publication of Moksha Publishing House. Website: www.mokshaph.com

(C) All rights reserved.

\section{ABSTRACT}

Psoriasis is a very common condition. The disorder may affect people of any age, but it most commonly begins between ages 15 and 35 . The condition is not contagious. There are five types of psoriasis: plaque, guttate, inverse, pustular and erythrodermic. The most common form, plaque psoriasis, is commonly seen as red and white hues of scaly patches appearing on the top first layer of the epidermis (skin).Psoriasis can be considered as one type of Kushtha. In Ayurveda texts it is a Krichchasadhya Vyadhi. It not fatal but it is responsible for great deal of unhappiness, feeling of depression at some point. Modern treatment gives temporary relief remissions and exacerbations are the rule in most of the psoriatic cases. Hence, there is a need for drugs having good efficacy in this debilitating disorder which is possible by Ayurvedic treatment. Sushuruta has stated 'Ubhayato Samshodhana' to be effective in the treatment of Psoriasis (Ekakushtha) but in old age samshodhan cannot be done. So Samshaman therapy plays vital role in Kustha. The present case study was carried out in IPD of Kayachikitsa department, Sir Sunder Lal Hospital I.M.S. B.H.U. Varanasi. The regimen has shown marked improvement in relieving all the symptoms and PASI score of the patients.

KEY WORDS: Ekakustha, Psoriasis, Samshamana, Scaling, Relapse

\section{INTRODUCTION}

Psoriasis (Ekakushtha) is one of the most common dermatologic disease, affecting up to 1 to 2 percent of the world's population equally men and women. It is chronic relapsing disease of unknown etiology characterized by sharply defined dry scaling erythematous patches, covered with adherent silvery white scales. Psoriasis can be considered as one type of Kushtha. In Ayurveda, almost all skin disease can be taken under generalized term "Kushtha". Apart from 18 types of Kustha(Ch.Ch.7/13), Psoriasis can be considered as Ekakushtha. Kushtha is produced invariably by the vitiation of the seven factors i.e. 3 Doshas and 4 Dushyas(Ch.Ch.7/9), specific manifestation of symptoms are produced in the way of different types of pain, colour, shape etc. Psoriasis is correlated with Kitibha, Sidhma, Ekakushtha etc. by different research workers but the clinical feature of Ekakushtha mentioned by Charaka Chikitsa (7/21) are very much similar with the Psoriasis (Ekakushtha) which are as follows :

1) Aswedanam - The lesions of this disease are dry and rough.

2) Mahavastum - Lesions are found all over the body.

3) Matsyashakalopama - Well defined raised macules, papules and plaques of erythema found which are covered with silvery scales.

4) Krishna - Aruna Varna- The lesions are raised and erythematous, thick lesion becomes black in colour.

The main etiological factors are Mithya Ahara-Vihara and Viruddha Ahara. In Ekakushtha dominant Dosha are Vatakapha(Ch.Ch.7/29) and Tvacha is the main Doshadhisthana (seat of disease). It is Chirakari and considered as a Sukhasadhya disease as per Charak but clinically its Krichchhasadhya disease. Topical medication Body-wide (Systemic), Phototherapy ${ }^{2}$ etc. are the general treatment options used in modern medical system for patient with psoriasis but they do not give complete cure but provides only temporary relief usually remissions and exacerbations occur. All Acharya have emphasized on Shodhana therapy in the management of all Kushtha because medicines given after Shodhana are more effective. After completing the Shodhana Karma, Shaman Chikitsa is indicated to subside the remaining Doshas. Shamana Chikitsa is very useful in those patients who are unable to undergo or contraindicated for Samshodhana. Charaka has advised Shamana therapy with Tikta and Kashaya Dravyas after administration of proper Shodhana (Ch. Chi. 7/58). Various forms of local application are prescribed like Udvartana, Pralepa, Parisheka, Abhyanga etc.

\section{CASE REPORT}

A 72 year old patient admitted in Feb 2010 with chief complaints of reddish patches all over the body and head, scaling of skin, severe itching all over the body for 3-4 years. For this he took treatment from different modern doctors but got no relief. Then he consulted the homeopathic, Ayurvedic doctors but all went in vain. Then he came to sir sunder hospital in Kayachikitsa O.P.D. for better management. Patient wanted to have Panchakarma but due to his age samshodhan cannot be given so; we planned the treatment in following way:

- Arogyavardhani Vati-250mg and Yashada Bhasma$200 \mathrm{mg}=2$ divided doses

- Swarnagarik-250mg, Gandhak Rasayana-1gm, Pravalpisti-500mg and Rasmanikya-150mg $=2$ divided doses

- Kumarkalyanarasa- $125 \mathrm{mg}=$ Once in Day

- Aragawadhapatra (Cassia fistula), Karveerpatra (Nerium indicum) and Kakmachipatra (Solonam nigrum) = Local application mixing with Takra

- Avgaha (Bath Sudation) with Shirisha Bark(Albizia lebbeck), Neem Bark(Azadiracta indica), Karanja Seed(Pongamia pinnata), Tulsipatra (Ocimum sanctum), Apamarga whole plant (Acryanthus aspera), 
Saptaparnapatra (Alstonia scholaris) daily after drying of above lepa.

The whole regimen was given for 15 days along with Pathya. After 2-3 days of treatment patient started improving and after 15 days therapy patient improved $50 \%$. Patient was called for 4 follow ups of 1 month. Now patient has improved completely, no relapse of symptoms have noticed in the patient after 1 year of therapy.
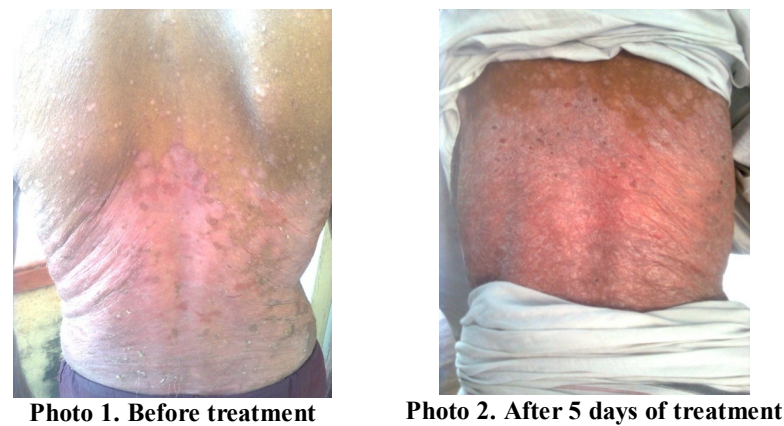

\section{RESULT}

The present regimen gave the relief to the symptoms mainly itching, indurations and scaling after few days of treatment and gradually redness of the skin also subsided. PASI score initially was 65 , after 5 days it reduced to 52 , after 15 days it was decreased to 37 and after six month it decreased to 6 (patient asymptomatic but occasionally start itching). After one year there was no recurrence.
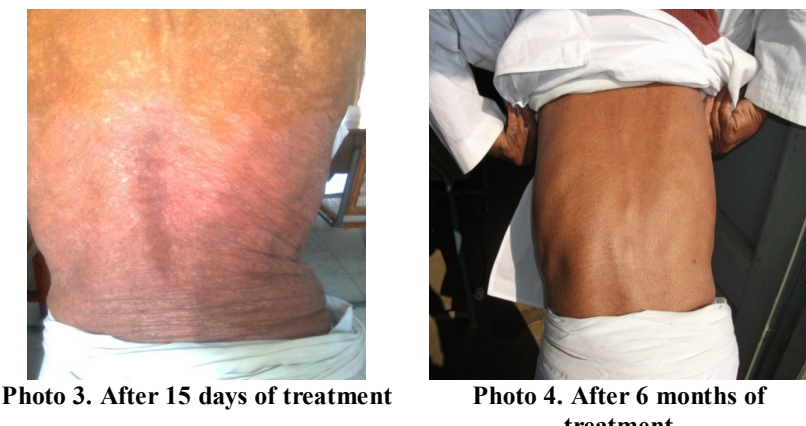

treatment

Photo No.1,2 and 3 was taken from $25 \mathrm{~cm}$ from the patient and Photo No.4 taken from $40 \mathrm{~cm}$ distance from the patient, and resolution $1024 \times 768$ (XGA)

\section{DISCUSSION}

Psoriasis is a major problem among the society till today. In Modern medicine drugs like steroid, ointments are used which give relief but not satisfactory and when drug is left psoriasis again flares up. Ekkustha is very near to psoriasis and it is counted as Shudrakustha hence Kushtahar drugs as well as immunity enhancing drugs can be beneficial for this morbid disease.

1.Arogyawardhini Vati $^{4}$ (R.R.S 20/87-93) is mentioned in Kushtaroga so it is useful in Ekkushta (psoriasis) because psoriasis is also comes under Mahakustha. Moreover Yasad Bhasma ${ }^{5}$ gives relief in Kandu (itching) which is chief complaints of Psoriasis.

2. Psoriasis is an autoimmune disorder, so Kumarkalyan Rasa $^{5}$ has swarna (gold) as the main ingredient used to enhance immunity of the patient which further, prevents the recurrence of disease.

3. Aragwadha is highly praised by Acharya Charaka he gave the separate chapter "Aragwadhiyaadhyaya" in Sutrasthana and Aragwadhadilepa (Aragwadha, Karveer and Kakmachi) is described for Kusthroga (Ch.Su.3/17)

Aragwadha, Karveer and Kakmachi contain Tikta, Kashaya Rasa so it may be acting as Vranshodhak and Vranaropan. Aragwadha is well known drug for Kustha and Kandu. ${ }^{3}$ Aragwadha is also described as Vedanahar, Shothahar and Dahashamak $^{14}$. It prevents secondary infection because it has antibacterial and has antifungal effects, ${ }^{7}$ it also has antiparasitic activity. ${ }^{18}$ Aragwadha has got anti-inflammatory ${ }^{20}$ action which help to reduce swelling, burning of lesion.

Kakmachi is also described as Kusthaghana ${ }^{3}$, Kandughana and Rasayan ${ }^{3}$ in Ayurvedic texts. It also has steroidal activity $^{8}$ and cytotoxic effect. ${ }^{10}$ Karveer is also well known drug for Kusthahar, Vranahar and Kandughana and it is scientifically proved as anti-inflammatory, ${ }^{9}$ cytotoxic drug. ${ }^{11}$ "Sirishovishaghananama" (Ch.Su.25/40) means Shirisha can be used in allergy disorder and it is also proved as mast cell stabilizer. ${ }^{14}$

4. In Charak Chikitsa-7 Acharya has described SiddhartakaSnana for Kustha Roga. Dravyas have been selected for Avgaha (Bath Sudation) which could act as
Kushtagna,Kanduhagna, Dahahar- Vednahara (antiinflammatory), Krimighna (antibacterial, antiparasitic).

Neem bark is well known useful traditional medicinal plant in India. It has Kanduhagna, Kushaghna ${ }^{21}$ Dahahar-Vednahara, Vranahar ${ }^{15}$ Krimighna ${ }^{22}$ properties. It has Anti-inflammatory, antipyretic and analgesic activities. It has immunostimulant, antifungal, antibacterial, antioxidant activity. ${ }^{23}$

Tulsi is used as antimicrobial ${ }^{12,16}$ which means that it prevents the secondary infections and also helps in dexamethasone suppressed wound healing. Neem, Karanj, Saptaparna and Apamarga contain Tikta Rasa so it acts as Vranashodak. Tulsi is use Kusthahara, Krimihara. Saptaparni and Karanja are used as Vranahara, Kusthhara and Krimihara. ${ }^{6}$

Apamarga is Swedjanan, Kusthaghana and Kandughana, Shulaghna. ${ }^{6}$ It also act as anti-inflammatory, wound healer, and has antioxidant activity ${ }^{13}$ and is antibacterial. ${ }^{17}$

\section{CONCLUSION}

Hence we can conclude that Shaman Chikitsa may be beneficial in Kustha Roga when vaman -virechan cannot be done as in present case. The above mentioned regimen showed excellent result in terms of relieving agonizing symptoms.

\section{REFRENCES}

1. Menter A, Gottlieb A, Feldman SR, Voorhees ASV, Leonardi CL, Gordon $\mathrm{KB}$, et al. Guidelines for the management of psoriasis and psoriatic arthritis. J Am Acad Dermatol. 2008; 5:826-850. http:// dx.doi.org/10.1016/j.jaad.2008.02.039

2. Stern RS. Psoralen and ultraviolet a light therapy for psoriasis. N Engl J Med. 2007; 357(7):682-690. http://dx.doi.org/10.1056/NEJMct072317

3. Shastri, K. Chaturvedi, G.N Charak., Charak Samhita, Vidyotini Hindi Commenatry , Pub. Chaukhabha Bharati Academy, Varanasi 2003;7:269-270

4. Indra DevTripathi Rasa Ratna Samucchaya, Rasa Prabha Tika,Hindi Commentary, $1^{\text {st }} \quad$ edition, Chaukhambha Sanskrit Bhavan,Varanasi, 1997;9:189

5. Ayurveda Sara Samgraha, Shri Baidyanatha Ayurveda, $18^{\text {th }}$ edition $1996 ; 243-244$

6. Chunekar, KC, Bhavaprakash Nighantu - Commentory (Hindi), edited by G.S. Pandey, ChaukhambaVidya Bhavan Varanasi 2005;198

7. Duraipandiyan, $\mathrm{V}$ and Ignacimuthu, S.,Antibacterial and antifungal activity of Cassia fistula L.: An ethnomedicinal plant. Journal of 
Ethnopharmacology 2007;112, 590-594. http://dx.doi.org/10.1016/ j.jep.2007.04.008

8. Zhou X., He X., Wang G., Gao H., Zhau G., Ye W. and Yao X. steroidal saponin from Solanum nigrum, Journal of natural products. 2006; 69:1158:1163.

9. B.Uma Reddy Antibacterial activity of Thevetia peruviana(pers.) K.schum and Neriumindicum Linn-The internet journal of pharmacology 2010;8:24-29

10. Kyung-Sun Heo, Sei-Jung Lee and Kye-Taek Lim.Cytotoxic effect of glycoprotein isolated from Solanum nigrum L.through the inhibition of hydroxyl radical-induced DNA-binding activities of NF-kappa B in HT29 cells, Environmental Toxicology and Pharmacology Volume 17, Issue 1, May 2004; 45-54.

11. Mae SH, Sofia M, Bolhuis RL, Nooter K, Oostrum RG, Subagus W, IbnuGG.Selectivity of compounds isolated from the leaves of Nerium indicum Mill. On various human cancer cell lines. Med J Malaysia. 2008 Jul; 63 Suppl A:24-5.

12. Mishra Poonam and Mishra Sanjay ,Study of Antibacterial Activity of Ocimum sanctum Extract Against Gram Positive and Gram Negative Bacteria,American Journal of Food Technology, Year: 2011 , Volume: 6, Issue:4;336-341.

13. Edwin S., Edwin E., Jarald, Deb L., Jain A., Kinger H., Dutt K.R., Amal Raj A.,Wound Healing and Antioxidant Activity of Achyranthes aspera, Informa health care(Pharmaceutical Biology), Vol. 46, No. 12, 2008; 824-828 http://dx.doi.org/10.1080/13880200802366645

14. Venkatesh P, Mukherjee PK, Kumar NS, Bandyopadhyay A, Fukui H, Mizuguchi H, Islam N. Anti-allergic activity of standardized extract of Albizia lebbeck with reference to catechin as a phytomarker, Immunopharmacol Immunotoxicol. 2010 Jun; 32(2):272-6. http:/ /dx.doi.org/10.3109/08923970903305481

15. Sharma P.V., Dravyagunavigana,vol-2, Chaukhabha Bharati Academy Varanasi.2001;3:143
16. Udupa, S L,Shetty, Somashekar,Udupa, A L,Somayaji, S N, Effect of Ocimum sanctum Linn. on normal and dexamethasone suppressed wound healing, Indian Journal of Experimental Biology IJEB Vol.44(01) January 2006;49-54.

17. Alam M. T., Karim M. M., Khan Shakila N.,Antibacterial Activity of Different Organic Extracts of Achyranthes aspera and Cassia alata, Journal of Scientific Research, vol-1,No.2, 2009;393-398.

18. Sartorelli,P., C.S.Carvalho, J.Q,Reimao, M.J.Ferrira and A.G.Tempone,2009.Antiparasitic activity of biochaninA,an isolated isoflabane from fruits of cassia fistula. Paracitol Research 104:311-314. http://dx.doi.org/10.1007/s00436-008-1193-z

19. Phongpaichit, S., Pujenjob, N., Rukachaisirkul, V. and Ongsakul, M. (2004). Antifungal activity from leaves extracts of Cassia alata L., Cassia fistula L. and Cassia tora L. Songklanakarin Journal of Science and Technology 26, 741-748.

20. Govianand,K.,Vivekanandan,P.,Pradeep KI.,Mohan,C.V.R., and Karthikeyan S.,2010 Antiinflamatory and Antipyretic activity of Indian medicinal plant cassia fistula Linn(Golden Shower)in wistar albino ratsInternational journal of pharmacology 2010,1-7.

21. Purandare N.S. , Apte V.G., Dhanwantari Nighantu - Raj Nighantu Sahito Dhanvantari Nighantu, Anandashrama, Pune 1896;23-27

22. Satyapal ,Kaiyadeva Nighantu - Hindi commentary, Chaukhamba Snaksrit Series, Varanasi, 1953;3:27

23. Biswas Kausik, Chattopadhyay Ishita, Banerjee Ranajit K. and Bandyopadhyay Uday,Biological activities and medicinal properties of neem (Azadirachta indica), current science, vol. 82, no. 11, June 2002;41-46

Cite this article as:

Antiwal Meera and Singh Jai Prakash. Role of Samshaman therapy in the management of Ekakushtha (Psoriasis): A case report. Int. Res. J. Pharm. 2013; 4(4):238-240 